\title{
Competitiveness Assessment the Construction Industry of the Republic of Tatarstan
}

\author{
Saubanov K.R. \\ Safiullin L.N. \\ Pratchenko O.V.
}

\author{
Kazan Federal University, Institute of Management, Economics and Finance, Kazan, 420008, Russia \\ Kazan Federal University, Institute of Language, 420008, Kazan, Russia
}

\section{Doi:10.5901/mjss.2014.v5n28p65}

\section{Abstract}

The article presents the results of a study aimed at testing the methodology for assessing the competitiveness of the regional construction sector. Assessment of competitiveness of the construction sector of the regional economy was conducted on three groups of indicators. The first group includes such indicators as the share of unprofitable enterprises in the construction, investment activity (share of investment in output). The second group of indicators includes labor Productivity, capital productivity, tend-vaginitis. The third group includes the ratio of wages in construction with the subsistence minimum working age population in the region, the degree of depreciation of fixed assets in the regional construction, the share of workers of construction organizations, working in conditions that do not meet hygienic standards of working conditions. The study showed that the competitive status of the construction industry of the Republic of Tatarstan within the framework of the three-factor model is the highest in the Volga Federal district. However, several challenges were identified. For example, regional authorities in the management of competitiveness of the construction complex of the region should pay attention to several issues related to performance and business activity in production and working conditions of their workers.

Keywords: competitiveness, construction industry, region, assessment of competitiveness, competitiveness, improving competitiveness.

\section{Introduction}

In our opinion, the study of competitiveness of the regional economy should be conducted in the context of analysis of the industry. Agricultural and industrial complexes of the regional economy were chosen as research subjects in a series of works on the problems of competitiveness of economy of the region $[4,5]$. Evaluation of competitiveness of the construction sector of the economy of the region as one of the key elements of the economy of the Republic of Tatarstan that provides the formation of 9,7\% of GRP (2011) and 10.6\% of working places (2012), was the next step that logically followed the first two.

Despite the objectively existing need for assessment of competitiveness of the regional socio-economic subsystems, now not enough attention is paid to the study of competitiveness of some industries and sectors of the regional economy. However, a large number of researchers study competitiveness of the entire region.

Most studies devoted to the methodological aspects of measuring the level of competitiveness in construction, focus on issues of competitiveness at the micro level.

Existing guidelines (methodic recommendations) for assessment the competitiveness of industrial enterprises and industrial production allowed the authors to classify and organize the material and to highlight the most important aspects of the methods proposed by different researchers.

Analyzing the domestic and foreign approaches for assessment the competitiveness at the micro level, L.M. Baumgarten points out that a lot of approaches of identification of complex indicators of competitiveness for organizations and production are the same and they use expert methods. Most of the methods of calculation of complex indicators of competitiveness are based on summation of individual indicators using their importance (weight), or without the latter. Therefore, two significant problems face the researcher when using the methods of evaluation of the complex index of competitiveness of organization and production: the choice of the most appropriate method; justification of significance (weight) of individual indicators of competitiveness [1]. Besides, in our opinion, the choice of the system of indicators of competitiveness is also a serious problem. This is the main difficulty of researchers who deal with problems of quantitative assessment of competitiveness of different objects. 


\section{Method}

Before to consider the possibilities of assessment of competitiveness of the regional building complex, it seems necessary to study the methodology of assessment of competitiveness of the industry.

I.A. Spiridonov says that the competitiveness of the industry is determined by the presence of its competitive advantages that allow you to create, manufacture (with costs not higher than the international ones) high quality products that meet the requirements of specific groups of customers (consumers) in relation to the customer value of goods, their market novelty and value (price) and deliver it to the competitive world market in the optimum time dictated by market conditions [7].

R.A. Fatkhutdinov proposes to evaluate the competitiveness of the industry by the leading large organizations, whose share is not less than $70 \%$ of sales in the industry [8].

According to the method of R.A. Fatkhutdinov, the level of competitiveness of the industry is determined by the following formula:

$$
K_{\text {OTP }}=\frac{\sum_{i=1}^{n} V_{i} \cdot K_{i}}{\sum_{i=1}^{n} V_{i}}
$$

where $K_{\text {OTP }}$ - the level of competitiveness of the industry that produces a homogeneous group of goods, unit fractions; $\mathrm{i}=1,2, \ldots, \mathrm{n}$ - the number of names of products in the group; $V_{i}$ - the market share of the I product; $K_{i}$ competitiveness of the I product in this (local, regional, national, international) market.

More extensive assessment methodology of competitiveness of the industry is offered in this work of T.A. Pavlova [3]; it assesses the industry competitiveness on the basis of the following indicators: trade flows/competitiveness in international markets; labor efficiency; efficiency of use of material-technical base; quality of products.

Operational performance, output-wages, the cost of 1 person-hour, return assets of fixed funds, return assets of new equipment and capital-labor ratio were used as the main factors of competitiveness of the industry and its performance indicators in the research study of competitiveness of sectors of the economy of the Republic of Tatarstan held in 2008 by GU "Center for Advanced Economic Studies" of the Academy of Sciences of the Republic of Tatarstan [6].

Summarizing the analyzed approaches for assessment of competitiveness of the industry, we have to say about the fact that the researchers point to the necessity of analysis of export-import transactions of products which the industry produces.

We carry out the comparative assessment of competitiveness of the construction sector of the Republic of Tatarstan in the Volga Federal District (PFD) on the following parameters:

1) Finance:

- The share of unprofitable enterprises in construction, \%;

- Investment activity (the share of investment in production output), \%.

2) Production:

- Operational performance, thousand rub. per 1 employee;

- Return asserts, 1 rub. of goods per 1 rub. of fixed assets;

- Capital-labor ratio, thousand rub. of fixed assets per 1 employee.

3) Labor conditions:

- The ratio of wages in construction to level of the cost of living of the working population in the region, \%;

- The wear-out rate of fixed assets in regional construction, \%;

- The share of workers of construction organizations who work in conditions that do not meet hygienic standards of working conditions, $\%$.

We offer to assess the competitiveness of the construction sector of the economy of the region on the basis of the approach proposed in the work of E.A. Nikolaeva and others [2], which is based on determination of ranks using the method of standard coefficients. This method allows us to turn the original data to a single scale and eliminates the effect of different units of measurement on the final result.

The aim of the method of standard coefficients is to bring the indicators measured in different units (kilograms, percent, etc.), to the value from 0 to 1 (where 0 corresponds to the worst result, and 1, respectively, - to the best). If the major indicator corresponds to the best result (i.e., the regions have to increase the value of the index), the following formula is used: 


$$
\bar{X}=\frac{X_{i j}-X_{\min i}}{X_{\max i}-X_{\min i}}
$$

where $X_{i j}$ - I indicator of $\mathrm{j}$ region, $X_{\min i}$ - the minimum value of the I indicator among the regions under study,

$X_{\max }$ - the maximum value of the $\mathrm{i}$ indicator among the regions under study.

If the minor indicator corresponds to the best result, the following formula is used:

$$
\bar{X}=1-\frac{X_{i j}-X_{\min i}}{X_{\max i}-X_{\min i}}
$$

\section{Results}

Now we will consider the possible directions of assessment of competitiveness of construction in the sectorial and - in particular - the regional aspect. And the system of indicators that can be used in assessing the competitiveness of the construction sector of the economy of the region is of particular interest.

We chose the building complex of the Republic of Tatarstan as a research object.

The data on the development of the construction industry of the Republic of Tatarstan in 2013 are presented in Table 1.

Table 1: Production output in the construction industry of the Republic of Tatarstan in 2013

\begin{tabular}{|l|c|c|c|c|c|}
\hline & $\begin{array}{c}\text { January- } \\
\text { December } \\
2013\end{array}$ & $\begin{array}{c}\text { In \% to January- } \\
\text { December 2012 }\end{array}$ & $\begin{array}{c}\text { December } \\
2013\end{array}$ & \multicolumn{2}{|c|}{$\begin{array}{c}\text { December 2013 in \% to } \\
2013\end{array}$} \\
\hline $\begin{array}{l}\text { Amount of work performed by organizations } \\
\text { of all activity types by the type of activity } \\
\text { "Construction", mln.rub. }\end{array}$ & 297232,2 & 100,1 & 49943,1 & 106,4 & 96,6 \\
\hline including large and medium-size enterprises & 100199,2 & 87,3 & 10473,6 & 102,9 & 66,8 \\
\hline $\begin{array}{l}\text { Start up of new housing supply into service, } \\
\text { thousand sqm of total floor area }\end{array}$ & 2400,3 & 100,0 & 254,9 & 129,2 & 70,2 \\
\hline
\end{tabular}

Source: Tatarstan-stat

As it can be seen from the table above, in 2013 construction work for a total amount of 297.2 billion rubles was carried out in the Republic of Tatarstan; it was $100.1 \%$ of the level of 2012. Thus, we can say about the slowdown of the rates of economic growth in the construction industry in the region in this period. The similar situation was in 2008 (Fig. 1) in conditions of the global economic crisis. Besides, if we compare the volume of production by the activity type "Construction" in December 2013 with December 2012, it was 96.6\%.

Fig. 1. Growth rate of production volume performed by the activity type "Construction" in the Republic of Tatarstan, \%

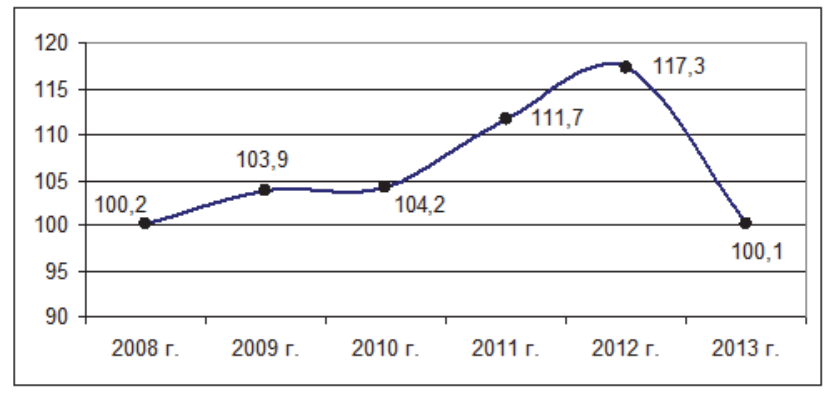

Thus, the situation in the construction industry of the Republic of Tatarstan is very difficult; it requires deeper and more comprehensive analysis.

Table 2 shows the calculations on the block "Finance". 
Table 2: Calculations on the block "Finance" of the construction complex of the regions of the Volga Region Federal District, 2012

\begin{tabular}{|c|l|c|c|c|}
\hline № & Region & $\begin{array}{c}\text { The share of unprofitable enterprises in } \\
\text { construction }\end{array}$ & $\begin{array}{c}\text { Investment } \\
\text { activity in } \\
\text { construction }\end{array}$ & $\begin{array}{c}\text { Average value of the index } \\
\text { indicators on the block }\end{array}$ \\
\hline 1 & Оренбургская область & 0,619 & 1,000 & 0,810 \\
\hline 2 & Самарская область & 1,000 & 0,330 & 0,665 \\
\hline 3 & Саратовская область & 0,835 & 0,083 & 0,459 \\
\hline 4 & Пензенская область & 0,831 & 0,072 & 0,452 \\
\hline 5 & Республика Татарстан & 0,674 & 0,196 & 0,435 \\
\hline 10 & Пермский край & 0,318 & 0,321 & 0,320 \\
\hline 14 & Ульяновская область & 0,000 & 0,000 & 0,000 \\
\hline
\end{tabular}

Source: calculations of the authors according to state statistics

As we can see from Table 2, the Republic of Tatarstan takes the $5^{\text {th }}$ place in the PFD $(0,435)$ by the average value of the index indicators of the block "Finance". In this case, if the index of the share of unprofitable enterprises in construction of the region is at a low level, the investment activity in the regional building complex (in accordance with the proposed methodological approach of its calculation) is insufficient.

Calculations on the block "Production" are presented in Table 3.

Table 3: Calculations on the block "Production" of the building complex of the regions of the Volga Region Federal District, 2012

\begin{tabular}{|c|l|c|c|c|c|}
\hline № & Region & $\begin{array}{c}\text { Work } \\
\text { performance }\end{array}$ & $\begin{array}{c}\text { Return on } \\
\text { assets }\end{array}$ & $\begin{array}{c}\text { Capital-labor } \\
\text { ratio }\end{array}$ & $\begin{array}{c}\text { Average value of index } \\
\text { indicators of the block }\end{array}$ \\
\hline 1 & Republic of Tatarstan & 1,000 & 0,272 & 1,000 & 0,757 \\
\hline 2 & Samarskaya province & 0,458 & 0,510 & 0,377 & 0,448 \\
\hline 3 & Ulyanovskaya province & 0,270 & 0,966 & 0,093 & 0,443 \\
\hline 10 & Nizhegorodskaya province & 0,261 & 0,461 & 0,272 & 0,331 \\
\hline 14 & Republic of Chuvashia & 0,000 & 0,199 & 0,212 & 0,137 \\
\hline
\end{tabular}

Source: calculations of the authors according to state statistics

As we can see from Table 3, the Republic of Tatarstan takes the $1^{\text {st }}$ place in the PFD $(0,757)$ by the average value of the index indicators of the block "Production". In this case, if by the indicator of work performance and capital-labor ratio the construction sector of Tatarstan demonstrates the strongest positions in the Volga Region Federal District, the rate of return on assets - in comparison with the other regions of the Volga Region Federal District - remains extremely low 0,272 .

Calculations on the block "Labor conditions" are presented in Table 4.

Table 4: Calculations on the block "Labor conditions" of the construction complex of the regions of the Volga Region Federal District, 2012

\begin{tabular}{|c|l|c|c|c|c|}
\hline № & Region & $\begin{array}{c}\text { The ratio of wages in the } \\
\text { construction with the level of } \\
\text { the cost of living of the } \\
\text { working population in the } \\
\text { region }\end{array}$ & $\begin{array}{c}\text { Wear-our rate of } \\
\text { fixed assets in } \\
\text { regional } \\
\text { construction }\end{array}$ & $\begin{array}{c}\text { Share of workers of the organizations of } \\
\text { construction who work in conditions that } \\
\text { do not meet hygienic standards of labor } \\
\text { conditions }\end{array}$ & $\begin{array}{c}\text { Average value of } \\
\text { index indicators } \\
\text { of the block }\end{array}$ \\
\hline 1 & Republic of Tatarstan & 1,000 & 1,000 & 0,099 & 0,700 \\
\hline 2 & Penzenskaya province & 0,669 & 0,247 & 1,000 & 0,639 \\
\hline 3 & Republic of Chuvashia & 0,444 & 0,873 & 0,450 & 0,589 \\
\hline 10 & Saratovskaya province & 0,390 & 0,625 & 0,199 & 0,405 \\
\hline 14 & Ulyanovskaya province & 0,148 & 0,531 & 0,000 & 0,226 \\
\hline
\end{tabular}

Source: calculations of the authors according to state statistics

As we can see from Table 4, the Republic of Tatarstan takes the $1^{\text {st }}$ place in the PFD $(0,700)$ by the average value of the 
index indicators of the block "Labour conditions". In this case, if by the indicators of the ratio of wages in the construction with the level of the cost of living of the working population in the region and by the wear-our rate of fixed assets in regional construction the construction industry is the leader in PFD, the share of workers of construction organizations who work in conditions that do not meet hygienic standards of labor conditions - in comparison with the other regions of the Volga Federal District - is extremely unsatisfactory - 0,099.

Aggregating all 3 blocks (finance, manufacturing, labor conditions) by determining their average value, we create the competitiveness rating of the construction complex of regions of Volga Federal District based on the author's methodology (tab. 5).

Table 5: Rating of competitiveness of the construction complex of regions of the Volga Federal District, 2012

\begin{tabular}{|c|l|c|c|c|c|}
\hline$№$ & Region & Block «Finance» & Block «Production» & Block «Labor conditions» & Average value of all blocks \\
\hline 1 & Republic of Tatarstan & 0,435 & 0,757 & 0,700 & 0,631 \\
\hline 2 & Samarskaya province & 0,665 & 0,448 & 0,570 & 0,561 \\
\hline 3 & Orenburgskaya province & 0,810 & 0,172 & 0,550 & 0,511 \\
\hline 4 & Penzenskaya province & 0,452 & 0,363 & 0,639 & 0,485 \\
\hline 5 & Republic of Bashkortostan & 0,340 & 0,408 & 0,537 & 0,428 \\
\hline 6 & Republic of Mordovia & 0,388 & 0,428 & 0,447 & 0,421 \\
\hline 7 & Saratovskaya province & 0,459 & 0,234 & 0,405 & 0,366 \\
\hline 8 & Kirovskaya province & 0,408 & 0,344 & 0,264 & 0,339 \\
\hline 9 & Republic of Mary El & 0,084 & 0,371 & 0,515 & 0,323 \\
\hline 10 & Nizhegorodskaya province & 0,100 & 0,331 & 0,525 & 0,319 \\
\hline 11 & Permsky region & 0,320 & 0,338 & 0,293 & 0,317 \\
\hline 12 & Republic of Chuvashia & 0,178 & 0,137 & 0,589 & 0,301 \\
\hline 13 & Republic of Udmurdiya & 0,386 & 0,152 & 0,282 & 0,273 \\
\hline 14 & Ulyanovskaya province & 0,000 & 0,443 & 0,226 & 0,223 \\
\hline
\end{tabular}

Source: calculations of the authors according to state statistics

Calculations showed that in 2012 the competitive status of construction industry of the Republic of Tatarstan was the highest in the Volga Federal District. The average value of the indices of all blocks (finance, manufacturing, labor conditions) was 0,631 .

\section{Conclusion}

Calculations made by the authors' methodology showed that in 2012 the competitiveness of the building complex of the Republic of Tatarstan is the highest among the other regions of the Volga Federal District. Low share of unprofitable enterprises (20,9\% - 2012), high indicators of work performance (1490,7 thousand rubles per 1 employee - 2012) and the capital-labor ratio (400,8 thousand rub les per 1 employee - 2012), a high level of average wages in comparison with the cost of living (486,4\% - 2012), a relatively low degree of depreciation of fixed assets $(37,5 \%)$ are the strengths of the construction sector of the economy of the region.

Despite the general competitiveness of the construction complex of Tatarstan in the Volga Federal District, the region has some weaknesses: low investment activity in comparison with the scale of the construction sector $(1,86 \%$ of investments in the amount of construction works - 2012), low return on assets productivity in the regional construction (3,7 rubles of gross amount of work for 1 ruble of fixed assets), a large share of workers of the construction organizations working in conditions that do not meet hygienic standards of labor conditions $(27,3 \%$ - 2012).

Thus, initial studies have showed that in the process of management of the competitiveness of the construction complex of the region the regional authorities should pay attention to a number of questions related to efficiency and business activity of production, as well as to labor conditions of workers of the industry.

\section{References}

Baumgarten L.V. Analiz metodov opredeleniya konkurentosposobnosti organizatsiy i produktsii // Marketing v Rossii i za rubezhom. 2005. - \#4.

Nikolaeva E.A., Vanchikova E.N., Mescheryakov S.A. Formirovanie i otsenka konkurentosposobnosti munitsipalnyih obrazovaniy 
regiona. - Ulan-Ude: VSGTU, 2006.

Pavlova T.A. Otsenka konkurentosposobnosti legkoy promyishlennosti v usloviyah vhozhdeniya Rossii v VTO. Avtoref. diss. ... k.e.n. Sankt-Peterburg, 2007.

Saubanov K.R. Otsenka konkurentosposobnosti selskogo hozyaystva Respubliki Tatarstan: Monografiya / K.R. Saubanov, R.H. Saubanov. - Kazan: Izd-vo TGGPU, 2008. - 164 s.

Saubanov K.R. Konkurentosposobnost promyishlennosti Respubliki Tatarstan: regionalnyiy aspekt: Monografiya / R.H. Saubanov, K.R. Saubanov. - Kazan: Izd-vo TGGPU, 2010. - 246 s.

Safiullin M.R., Demyanova O.V. Sovremennyie tendentsii otsenki konkurentosposobnosti regiona na primere Respubliki Tatarstan // Ekonomicheskiy Vestnik Respubliki Tatarstan. - 2008. - \#5; Demyanova O.V. Tri kita konkurentosposobnosti Tatarstana // Vremya i Dengi. - 2008. - \#53.

Spiridonov I.A. Mezhdunarodnaya konkurentsiya i problemyi povyisheniya konkurentosposobnosti ekonomiki Rossii. - M.: MGOU, 1996.

Fathutdinov R.A. Strategicheskiy marketing. 2-e izd., pererabotannoe i dopolnennoe. - SPb.: Piter, 2002.

Razumovskaya, E.M.,Mishakin, T.S., Popov, M.L., Kucevol, N.G. Medical services during the XXVII world summer universiade 2013 in Kazan. Mediterranean Journal of Social Sciences vol. 5 (18 SPEC. ISSUE), pp. 17-20

Arustamyan, G.,Yegorov, E., Lipsky, S.,Razumovskaya, E.,Gimranova, L. Clinical and economic analysis and its role in healthcare quality management. World Applied Sciences Journal vol. 27 (3), pp. 318-323.

Ayupov A.A., Kazakovtseva M.V. Management of Financial Stability of the Non-Tax Income of Regional Budgets. Procedia - Social and Behavioral Sciences Vol. 131, pp. 187-192 // 3rd World conference on educational technology researches Turkey 07-09.10.2013. 